Article

\title{
Evaluating the Effects of Low Impact Development Practices on Urban Flooding under Different Rainfall Intensities
}

\author{
Zhihua Zhu ${ }^{1,2,3}$ and Xiaohong Chen ${ }^{1,2,3, *}$ \\ 1 Center for Water Resources and Environment, Sun Yat-sen University, Guangzhou 510275, China; \\ persistzhzh@163.com \\ 2 Guangdong Engineering Technology Research Center of Water Security Regulation and Control for \\ Southern China, Sun Yat-sen University, Guangzhou 510275, China \\ 3 Key Laboratory of Water Cycle and Water Security in Southern China of Guangdong High Education \\ Institute, Sun Yat-sen University, Guangzhou 510275, China \\ * Correspondence: eescxh@mail.sysu.edu.cn; Tel.: +86-20-84114575
}

Received: 30 March 2017; Accepted: 12 July 2017; Published: 24 July 2017

\begin{abstract}
Low impact development (LID) is an important control measure against extreme rainfall events and is widely applied to relieve urban flood disasters. To investigate the effects of LID practices on flooding control under different rainfall scenarios, this paper constructs a rainfall-runoff model based on the storm water management model (SWMM) for a typical residential area in Guangzhou, China. The model is calibrated by using observed rainfall and runoff data. A total of 27 rainfall scenarios are constructed to simulate the change characteristics before and after the LID practices. Also, the projection pursuit method based on a particle swarm optimization (PSO) algorithm is used to assess the flooding characteristics. The results show that the constructed rainfall-runoff model can closely reflect the relationship between rainfall and runoff, with all Nash-Sutcliffe coefficients of efficiency (NSE) exceeding 0.7. It was found from the simulation and assessment of the constructed rainfall scenarios that the changes in rainfall characteristics have a considerable impact on the constructed drainage system and that LID practices can properly control the floods. However, with an increase in rainfall peak coefficient, intensity or duration, the control effects of LID tend to reduce. Particularly in the scenario of relatively high rainfall intensity, the impact of rainfall duration and the rainfall peak coefficient on the LID practices is minor.
\end{abstract}

Keywords: urban drainage system; different rainfall scenarios; control characteristics; urban runoff control; flood mitigation; low impact development (LID); China

\section{Introduction}

Along with significant changes in global climate and the considerably increasing disturbance caused by human activities, flood disasters in urban areas have become more serious, substantially restricting social and economic development and posing a threat to the safety of human lives and properties [1,2]. In recent years, urban flooding has caused many casualties and property losses in Japan, Singapore, The Netherlands, Britain and other countries [3-6]. Many major cities in China have also been greatly influenced by urban flooding disasters, including Guangzhou, Wuhan, Shenzhen, Nanjing, Beijing [7]. The key issue is that the drainage systems of these areas cannot adapt to climate change and human activity. Therefore, there is an urgent need to control flood disasters from a design perspective.

In order to alleviate the problem of urban flooding disasters, many strategies of flood mitigation and disaster relief have been put forward [8-10]. The traditional efforts include the following: 
(i) improving the capacity of the drainage system. For example, Guangzhou requires the improvement of the drainage system capacity in areas through new construction [11]. Hong Kong and Chicago have introduced similar policies to improve drainage capacity [12]. The main measures used to improve the drainage capacity are to expand the existing drainage system and to construct a deep drainage system. (ii) Build water diversion and storage projects. Due to the restrictions on urban land resources, Singapore, Hong Kong, and Japan have constructed drainage pipes to divert water and water storage works to reduce the burden on downstream drainage $[13,14]$. (iii) Improve flood prevention ability. Many countries use road blocks, raise the height of existing dams, install flood gates and use other measures to prevent urban floods [14]. (iv) Implement routine maintenance of drainage systems. In order to prevent blockages in the pipe network, a common measure is to clean out solid waste in the pipes and strengthen routine maintenance of the pipe network, so as to prevent waste from entering the pipe network. However, all of these measures are generally expensive with large scale construction or can easily lead to excessive drainage of downstream areas. In highly developed urban areas, these drainage-based control measures and end-control measures do not adequately address urban floods, so it is important to find new methods to control the source of the runoff.

Due to the lack of necessary rain and flood control measures, and the unsustainable nature of traditional flood management, developed countries have studied urban flood disasters scenarios since the 1970s based on the requirements of the flood discharge space. After decades of development, a relatively complete system of urban rain and flood management has been set up in many countries [15]. A system's flood management is based on the comprehensive and multi-level considerations of individual buildings, flood drainage, runoff control and other elements. Certain well-known management measures include low impact development (LID) and best management practices (BMPs) proposed by the United States, water sensitive urban design (WSUD) proposed by Australia, sustainable drainage systems (SUDS) proposed by the Britain, and low impact urban design and development (LIUDD) proposed by New Zealand [16]. These concepts and measures place high value on the combination of structural measures and non-structural measures, as well as on natural drainage conditions and landscape features, to effectively control urban floods.

LID has been rapidly developed in Europe, the Middle East, Asia, Africa and South America [17]. It refers to a stormwater management method based on the simulation of natural hydrological conditions, causing no changes in urban hydrological characteristics. It uses ecological measures, source control and distributed control measures to accomplish stormwater control and utilization [18]. Different LID practices have different characteristics (Table 1) [19]. It results in satisfactory effects through the combined use of reservoirs, green roofs, rain gardens, bioretention swales and bioretention ponds [20,21]. The community and street reconstruction project in Seattle and the bioretention pond system implemented in the Portland Expo Center are exemplary of this approach. Additionally, Berlin Potsdamer Platz and a certain ecological urban area in Hanover, which were designed based on LID, have obtained remarkable effects [22]. According to the estimates of Unified Facilities Criteria, the LID market may have amounted to $\$ 380$ billion in the United States in recent years, greatly encouraging the research, development and promotion of LID. Also, LID is vigorously promoted in China [23-25]. However, the application of LID in China is mainly confined to small-scale areas at present [26]. Also, no attention has been paid to the role of various elements and projects in the rainwater systems, and the response characteristics of different climates to LID have not been taken into account.

In order to have a clearer idea of the performance of various LID practices, the storm water management model (SWMM) of United States Environmental Protection Agency (USEPA) [27] has been widely used for simulations. Extensive research has been conducted into the performance of the SWMM model in simulating hydrologic processes [28]. For example, Burszta-Adamiak et al. [28] simulated green roof hydrologic performance based on the SWMM model. Qin et al. [29] analyzed the effects of LID on urban flooding using the SWMM model. Alfredo et al. [30] proved that green roofs can reduce $30-78 \%$ of peak runoff and delay the runoff to some extent as well. Niu et al. [31] simulated the long-term effect of LID and indicated that LID has a remarkable effect on water balance 
in highly urbanized areas. Ahiablame et al. [17] probed the flood control ability of LID in an effort to find the optimal way to control floods. Bedan and Clausen [32] found that arranged LID could reduce rainfall runoff by $42 \%$ and purify water. In addition, many researchers hope to obtain the optimal combination of flood control by analyzing and comparing the performance of porous pavements, green roofs, bioretention swales and other LID components [33-35].

Table 1. Comparison of some Low Impact Development (LID) practices [19].

\begin{tabular}{|c|c|c|c|c|c|c|}
\hline \multirow[b]{2}{*}{ LID Practices } & \multirow[b]{2}{*}{ Storage } & \multicolumn{2}{|c|}{ Functions } & \multicolumn{2}{|c|}{ Cost } & \multirow{2}{*}{$\begin{array}{l}\text { Scenic } \\
\text { Effect }\end{array}$} \\
\hline & & Transportation & $\begin{array}{l}\text { Reducing Runoff } \\
\text { Peak Rate }\end{array}$ & $\begin{array}{l}\text { Construction } \\
\text { Cost }\end{array}$ & $\begin{array}{l}\text { Maintenance } \\
\text { Cost }\end{array}$ & \\
\hline Rain garden & A & A & A & $\mathrm{C}$ & B & A \\
\hline Dry bioretention swales & $\mathrm{C}$ & $\mathrm{A}$ & A & A & A & $\mathrm{A}$ \\
\hline Wet bioretention swales & $\mathrm{C}$ & A & $\mathrm{C}$ & B & A & $\mathrm{A}$ \\
\hline Green roof & $\mathrm{C}$ & C & $\mathrm{C}$ & $\mathrm{C}$ & B & A \\
\hline Porous pavement & $\mathrm{C}$ & B & B & A & A & - \\
\hline Subsided Green space & $\mathrm{C}$ & $\mathrm{B}$ & B & $\mathrm{A}$ & A & B \\
\hline Wet pond & A & $\mathrm{B}$ & $\mathrm{A}$ & $\mathrm{C}$ & $\mathrm{B}$ & A \\
\hline Vegetative filter strip & $\mathrm{C}$ & $\mathrm{C}$ & $\mathrm{C}$ & A & A & $\mathrm{B}$ \\
\hline
\end{tabular}

Note: A represents ideal performance; $\mathrm{B}$ represents average performance; $\mathrm{C}$ represents low performance.

Compared with traditional flood control measures, LID practices are more flexible in response to climate change, which is a very important aspect for government decision-makers [36]. Also, it is considered to be a pivotal approach to sustainable urban development. Nevertheless, most studies consider only laboratory scenarios or one particular rainfall scenario. Research into the response characteristics of LID under different rainfall scenarios is sparse. In addition, the evaluation of LID practices is mainly based on the evaluation of a single factor (such as increasing peak flow attenuation, increasing lag time, flow attenuation of stormwater runoff, etc.), and it has mainly evaluated at the multidimensional scale, which is likely to cause dimensionality when a multi-factor evaluation is performed.

A large number of studies have shown that the mastering of LID control characteristics and accurately evaluating the control of LID practices under different rainfall scenarios can effectively respond to urban flood disasters and guide the formulation of appropriate measures. Therefore, a rainfall-runoff model is constructed based on the SWMM model [27]. When a large number of scenarios is considered, a better optimization procedure is required. In this paper, 27 rainfall scenarios with different rainfall intensities, rainfall durations and rainfall peak coefficients are considered and a comprehensive assessment of the change characteristics of floods is conducted in various rainfall scenarios by using particle swarm optimization (PSO)-based projection pursuit technology [37] which includes (1) the discovery of the response law of the pipeline network to different rainfall intensity before and after the implementation of LID practices; (2) the qualitative and quantitative evaluation of the variation characteristics of the flood before and after the implementation of the LID practices; and (3) the recognition of the control characteristics of LID under different complex scenarios.

\section{Study Area}

Guangzhou $\left(22^{\circ} 26^{\prime}-23^{\circ} 56^{\prime} \mathrm{N}, 112^{\circ} 57^{\prime}-114^{\circ} 03^{\prime}\right.$ E) has a tropical and subtropical monsoon climate with extremely significant characteristics of a monsoon climate and subtropical westerly, equatorial westerly and tropical easterly winds. The area is abundant in rainfall, with average annual rainfall of $1675.5 \mathrm{~mm}$, and characterized by a long rainy season and heavy rainfall of great intensity and nonuniform spatial distribution. The rainfall is mainly concentrated in the months from April to September that are affected by warm air. The rainfall from April to September accounts for $80 \%$ of annual rainfall. The rainfall in May and June represents $32 \%$ of the annual rainfall. Since the reform and opening policies in the 1980s, the forms of land use in Guangzhou have changed substantially. 
Land under construction is constantly being expanded, contributing to changes in the characteristics of runoff and to increasingly serious urban flooding.

In order to probe the flood control characteristics of LID practices under different rainfall scenarios, this paper selected a typical highly-developed residential area. It covers a total of $3.13 \times 10^{5} \mathrm{~m}^{2}$ and is primarily used for construction with some land set aside for green space and transportation (Figure 1). The drainage system uses a rainwater and sewage separation system, and its design standard is based on a 2-year rainfall intensity developed by the Guangzhou Water Affairs Bureau in 1993 (with pipe diameter between 900 and $2000 \mathrm{~mm}$ and slopes between 0.001 and 0.01 ).

The study area is divided into 19 sub-catchments, and the drainage system is generalized into 31 drainage pipes, 31 manholes and 1 drainage outlet (Figure 1) in accordance with land use, the pipe laying situation, the terrain and other data. The rainfall-runoff model is constructed based on the SWMM model to reflect the relationships between runoff and rainfall. Point A (in the downstream area) is selected to record the runoff, and the flow and rainfall are recorded simultaneously in accordance with a flow meter and rain gauge at an interval of 10 min (Figure 1).

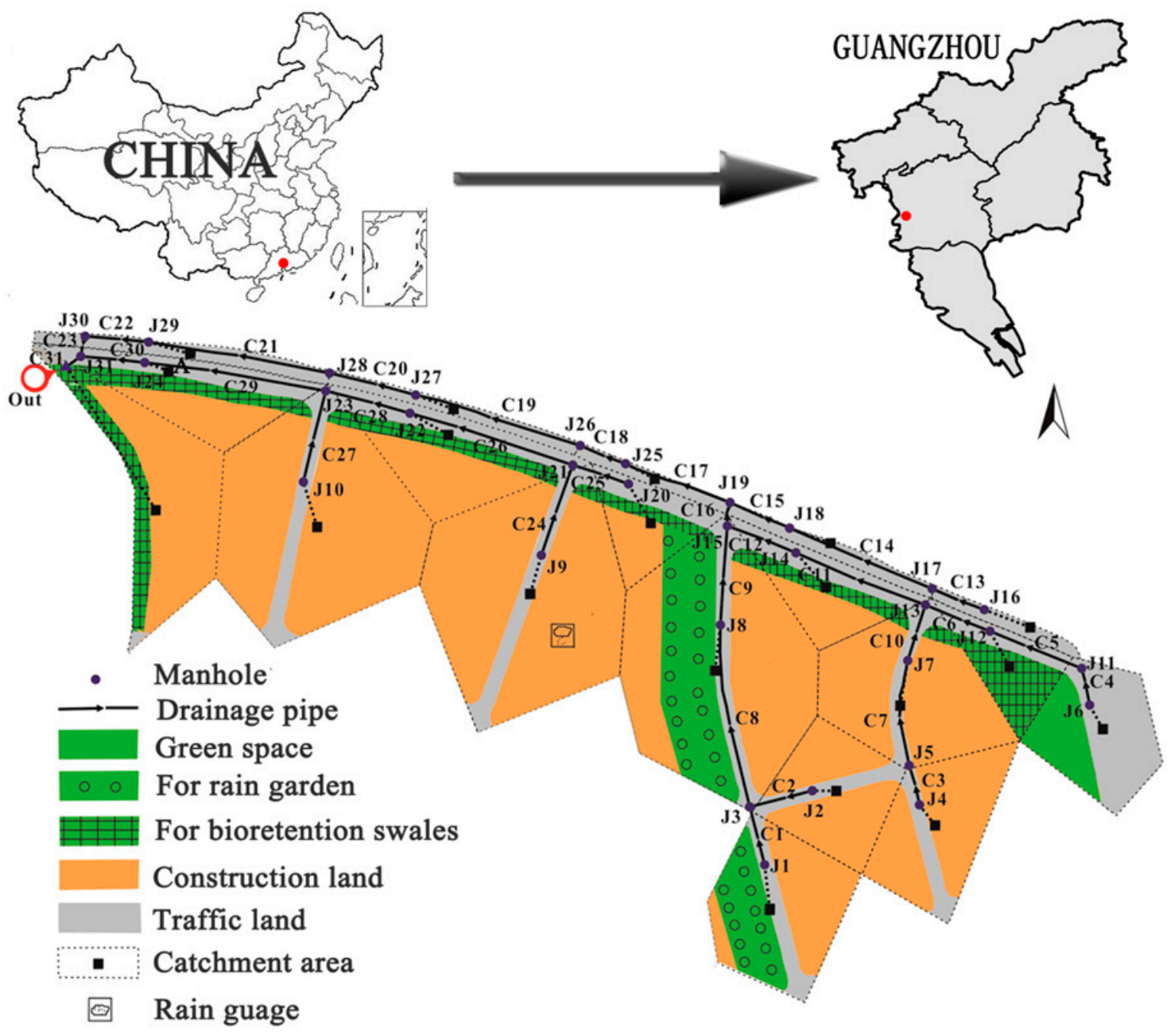

Figure 1. Generalized results of the land use and drainage system.

\section{Methodology}

In order to investigate the control characteristics of the highly-developed area under different rainfall scenarios after the implementation of LID practices, the observed rainfall-runoff data was employed to calibrate and verify the rainfall-runoff model based on the SWMM model. Also, different rainfall scenarios were constructed based on the rainfall intensity formula in Guangzhou [38] and 
the Chicago Hydrograph Model [39]. The characteristics of flood change (before and after LID) were analyzed by PSO-based projection pursuit technology.

\subsection{SWMM Model}

The SWMM model is a relatively flexible hydrodynamic model developed by USEPA [27], based on the physical mechanisms of mass, energy and momentum conversion, as well as a comprehensive mathematical model constructed for the mechanisms of runoff generation [27]. It can properly simulate the rainfall-runoff relationship, pollutant dispersion, flood control and other hydrological processes in urban areas under natural conditions. Also, the SWMM model is widely used to simulate the hydrologic performance of natural channels, rain and sewage diversion systems or other drainage systems, and it can evaluate the design of LID practices and BMPs. Much research on the SWMM model can be found [40-42].

The SWMM model provides different modules and algorithms for simulation as described below.

\subsubsection{Surface Runoff Simulation Module}

When the SWMM model is included in the calculation of surface production, the sub-basin is regarded as a non-linear reservoir, and the surface runoff refers to the rainfall depth after infiltration and surface water storage. The surface water storage modules are different for different regions. The SWMM model provides the Horton model, the Green-Ampt model and the curve number model to calculate the infiltration. This paper chooses the Horton model for calculating small watersheds. The flow is transformed into the outflow process and the process in which flow changes over time, and the two processes are calculated separately using Manning's equation and the finite difference method.

\subsubsection{Transmission Calculation Module}

The main method for calculating the flow of the pipe network is the Saint-Venant equation. In the SWMM model, three methods (steady flow routing, kinematic wave routing and dynamic wave routing) are used for pipe network transmission calculation. The kinematic wave routing method is used in this paper.

\subsubsection{Flood Calculation Module}

If the depth of the node exceeds the maximum available depth, overflow is lost from the system or water is saved at the top of the node, and it re-enters the drainage system under specific conditions. The SWMM model can simulate the approximate location of the overflow, the distribution and the corresponding overflow.

\subsubsection{LID Module}

The SWMM model can simulate the control effect of LID practices, and seven different types are provided: bio-retention cell, porous pavement, infiltration trench, rain barrel, vegetative swale, rain garden and green roof. In the SWMM model, different types of LID practices are divided into several vertical layers and represented by five to 23 parameters (e.g., thickness, surface roughness, offset height). More details about this can be found in [27].

The SWMM model's user manual [27] provides a range of values for sensitive parameters based on a large number of simulation studies; this provides references for calibrating the model's parameters. Thus, the recommended range of the parameters and the trial and error approach are used.

\subsection{Evaluation of Model Accuracy}

The Nash-Sutcliffe Efficiency (NSE) coefficient, which is often considered to be one of the most important indices for measuring the model's simulation accuracy [43], was used to evaluate the accuracy of the constructed model simulation results. Its expression is as follows: 


$$
N S E=1-\frac{\sum_{i=1}^{n}\left(S_{i}-O_{i}\right)^{2}}{\sum_{i=1}^{n}\left(O_{i}-\bar{O}_{i}\right)^{2}}
$$

where $n$ means the total number of time-steps; $S_{i}$ represents the simulated value at time-step $i ; O_{i}$ represents the observed flow at time-step $i$; and $\bar{O}$ is the average value of the observed flow. When $N S E=1$, the observed flow is consistent with the simulated flow. If NSE is within the range of 0 to 1 , the simulated flow is acceptable. If NSE is greater than 0.5 , the simulation results are satisfactory $[44,45]$.

\subsection{Projection Pursuit Method}

The projection pursuit method is mainly used to project high-dimensional data to low dimensions, to avoid "dimension disaster". The characteristics of the original data are described by the optimal projection direction and projection values [46]. It has been widely applied to water resource assessment, engineering stability assessments and many other applications [47-49]. Compared with traditional methods (e.g., neural networks and principal component analysis), this method can eliminate the influence of subjective factors.

Since the flooding of an urban drainage system involves a large number of indices, it is difficult to comprehensively assess all of the flood characteristics through high-dimensional indices and data. According to the mechanisms and objectives of urban flooding analysis, the volume of flooding, the maximum flooding rate and the duration of flooding are selected as indices used to assess the characteristics of the flooding. A high-dimensional flood evaluation system may be reduced to a one-dimensional system in order to comprehensively evaluate the regional flood characteristics using the projection pursuit method. The calculation steps are as follows:

Step (1): Normalize the evaluation index. As the evaluation indices have different dimensions and lack comparability, they must be normalized. Assume an evaluation index set $x^{*}=$ $\left\{x_{i j} \mid i=1,2, \ldots, n ; j=1,2,3\right\}$, where $x_{i j}$ is the $j^{\text {th }}$ index value of the $i^{\text {th }}$ sample, and $n$ is the sample size. A large number of studies have shown that the selected indices are positively related to flood evaluation. Therefore, all indices are used in Equation (2) to normalize $x_{i j}$ to $X_{i j}$.

$$
X_{i j}=\frac{x_{j \max }-x_{i j}}{x_{j \max }-x_{j \min }}
$$

where $x_{j \max }$ and $x_{j \min }$ are the maximum and the minimum of evaluation index $j^{\text {th }}$ of all samples respectively.

Step (2): Find the function of the construct projection index. The flooding evaluation index is expressed as a one-dimensional projection value $Z_{i}=\sum_{j=1}^{p} a_{j} x_{i j} \quad(i=1,2, \ldots, n)$ in the projection direction $\alpha=\left\{\alpha_{j} \mid j=1 \sim p\right\}$. Therefore, the construction of the projection index function $Q(a)$ is as follows:

$$
Q(a)=S_{Z} D_{Z}
$$

where $S_{Z}$ and $D_{Z}$ indicate the standard deviation and local density of $Z_{i}$, respectively, i.e.,

$$
\begin{gathered}
S_{z}=\sum_{i=1}^{n} \sum_{j=1}^{p}(R-r(i, j)) \cdot u(R-r(i, j)) \\
D_{z}=\sqrt{\frac{\sum_{i=1}^{n}\left(Z_{i}-\bar{Z}\right)^{2}}{n-1}}
\end{gathered}
$$


where $R$ is radius of the window, and it is usually $0.1 \sqrt{\frac{\sum_{i=1}^{n}\left(Z_{i}-\bar{Z}\right)^{2}}{n-1}} ; P$ is the number of indices; $r(i, j)$ is the distance between samples; and $u(R-r(i, j))$ is the unit step function. If $R-r(i, j) \geq 0$, then $u(R-r(i, j)=1$; if $R-r(i, j)<0$, then $u(R-r(i, j)=0$.

The change in the projection index function $Q(a)$ is determined by the projection direction. When $Q(a)$ is maximized, it is considered to be the most likely function to represent the structural features of high dimensional data, and the corresponding vector is the best projection direction $\alpha^{*}$, where $\alpha^{*}$ is the projection direction vector involving the maximum number of high-dimensional data characteristics. The maximization of the objective function and its corresponding constraints are denoted by (6) and (7), respectively.

$$
\begin{gathered}
\max Q(a)=S_{z} D_{z} \\
\sum_{j=1}^{p} \alpha_{j}^{2}=1
\end{gathered}
$$

Step (3): Solving the objective function. The objective function (6) is a complex nonlinear system which needs to be solved by advanced optimization algorithms. A large number of studies have shown that the PSO algorithm has significant versatility in high-dimensional global optimization with simple and effective operation [50-53]. It is therefore used to solve the objective function in this study. The PSO algorithm is a heuristic search method that treats a solution to a problem as a "particle" of the search space. The basic idea is to initialize a group of random particles (i.e., random solutions), and then find the optimal solution by iterative calculations. The velocity, position and fitness of the particle $d$ are $V_{d}, S_{d}, f_{d}(d=1,2, \ldots, N), N$ is the pre-defined number of particles. During each iteration, the optimal solution (individual optimal value $p_{d}(t)$ ) will be found by the particle through the particles themselves, and the optimal solution (global optimal value $g_{d}(t)$ ) found among the entire population of particles during each calculation updates the position and velocity of the particle. Its update rules are as follows:

$$
\begin{gathered}
V_{d}(t+1)=w V_{d}(t)+\left(c_{1} b_{1}(t)+c_{2} b_{2}(t)\right) \cdot\left(p_{d}(t)-s_{d}(t)\right) \\
S_{d}(t+1)=S_{d}(t)+V_{d}(t+1)
\end{gathered}
$$

where, $t$ is the current iteration as inertia weight; $c_{1}$ and $c_{2}$ represent individual learning factor and group learning factor, respectively; and $b_{1}(t)$ and $b_{2}(t)$ represent the individuals and groups of particles, respectively. In this paper, 150 random particles are initialized, and the maximum number of iterations is set to 1500. The maximum and minimum weighting factors are 0.9 and 0.4 , respectively. $c_{1}=c_{2}=2$ gave the best overall performance [54,55]. Therefore, $c_{1}$ and $c_{2}$ are kept as constant of 2 . In the iterative calculation process, the update rules of the individual optimal value and the global optimal value are shown in (10) and (11).

$$
\begin{aligned}
p_{d}(t+1)= & \begin{cases}S_{d}(t+1) & f_{d}(t+1) \geq f\left(p_{d}(t)\right) \\
p_{d}(t) & f_{d}(t+1)<f\left(p_{d}(t)\right)\end{cases}
\end{aligned}
$$

where $f_{d}(t+1)$ is the fitness value of the iteration of particle $d$ in $t+1$.

To solve the coupling between PSO and the projection pursuit method, we use the following procedure:

Step (1) Put $S_{d}(t+1)$ into $Z_{i}=\sum_{j=1}^{p} a_{j} x_{i j} \quad(i=1,2, \ldots, n)$ to calculate the value of $Z_{i}$

Step (2) Use Equation (4) and (5) for calculating $S_{z}$ and $D_{z}$

Step (3) Use Equation (3) to calculate $Q(a)$, that is $f_{d}(t+1)$ 
When $f_{d}(t+1)=f_{d}(t)$, or it achieves the maximum number of iterations, the resulting $g_{d}(t)$ is equal to $\alpha^{*}$.

Step (4) Analyze the flood characteristics. $\alpha^{*}$ will be substituted into the formula $Z_{i}=\sum_{j=1}^{p} a_{j} x_{i j} \quad(i=$ $1,2, \ldots, n)$ to obtain the best projection value for each manhole $Z_{i}^{*}$; the greater the projection value is, the larger the flood.

\subsection{Setting of Rainfall Scenarios}

Rainfall design is the basis and premise for planning regional drainage systems and flood control measures. To probe the impact of climate change on rainfall, the Guangzhou Water Affairs Bureau analyzed serial information about rainfall from the most recent 60 years in 2011 [38], compared the information with the Guangzhou rainstorm formula enacted in 1993 [56] and introduced a rainfall intensity formula more in line with the rainstorm characteristics of Guangzhou (Table 2). A total of 27 designed rainfall events, which are composed of different return periods (one year, five years and ten years), rainfall duration $(1 \mathrm{~h}, 1.5 \mathrm{~h}$ and $2 \mathrm{~h})$ and rainfall peak coefficients $(0.375,0.5$ and 0.8$)$, were selected to investigate the control effects of LID practices. Here, the rainfall peak coefficient means the time that the rainfall peak occurred divided by the rainfall duration.

Table 2. Design rainfall intensity $i(\mathrm{~mm} / \mathrm{min})$ of Guangzhou in different rainfall return periods, $P$ (years) [38].

\begin{tabular}{cc}
\hline $\boldsymbol{P}$ & $\boldsymbol{i}$ \\
\hline$P=2$ & $\frac{5230.65(1+0.438 \mathrm{Lg} P)}{167(t+14.646)^{0.815}}$ \\
\hline$P=5$ & $\frac{4143.327(1+0.438 \mathrm{Lg} P)}{167(t+12.874)^{0.758}}$ \\
\hline$P=10$ & $\frac{3512.11(1+0.438 \mathrm{Lg} P)}{167(t+11.61)^{0.717}}$ \\
\hline
\end{tabular}

Note: $i$ is design rainfall intensity, $t$ (hour) is rainfall duration and $P$ is rainfall return period.

\section{Results and Discussion}

\subsection{Calibration and Verification of Model Parameters}

According to the observed rainfall-runoff data, the principles of the SWMM model and the recommended parameters, five rainfalls were selected to calibrate the parameters. Based on the sensitivity analysis of the SWMM model parameters, the trial and error approach was used to calibrate the parameter values repeatedly until the simulation results agreed with the observation results. The determined model's main sensitivity parameters are shown in Table 3. The simulation runoff process was obtained by repeatedly calibrating the model's parameters, and the change process of the observed runoff was consistent with the simulated runoff (Figure 2 and Table 4). The correlation coefficient $\left(R^{2}\right)$ between the simulated flow and the observed flow and NSE coefficient exceed 0.91, and the peak relative error remained within $5 \%$. From the rainfall-runoff process, the constructed regional rainfall-runoff model accurately reflects the relationship between runoff and rainfall.

To verify the rationality and reliability of the calibrated parameters, five different rainfall scenarios were selected for parameter verification (Table 4). The results show that the NSE coefficients between the simulated runoff and observed runoff exceed 0.7 , that $R^{2}$ is greater than 0.86 , and that the discharge relative error and the flood peak relative error are less than $5 \%$. Therefore, the constructed rainfall-runoff model is believed to be highly accurate. 
Table 3. Values and ranges of the main sensitivity parameters of the rainfall-runoff model.

\begin{tabular}{|c|c|c|c|}
\hline \multicolumn{2}{|c|}{ Parameter } & $\begin{array}{c}\text { Recommended } \\
\text { Parameter Range [27] }\end{array}$ & $\begin{array}{l}\text { Parameter Range of the } \\
\text { Rainfall-Runoff Model }\end{array}$ \\
\hline \multicolumn{2}{|c|}{ Flow Width } & / & $10 \mathrm{~m} \sim 277 \mathrm{~m}$ \\
\hline \multicolumn{2}{|c|}{ Imperviousness } & $0 \sim 100 \%$ & $25 \%$ \\
\hline \multirow{3}{*}{$\begin{array}{l}\text { The Manning } \\
\text { roughness coefficient }\end{array}$} & $\begin{array}{l}\text { Impervious area Manning's } \\
\text { roughness }\end{array}$ & 0.015 & $0.011 \sim 0.015$ \\
\hline & $\begin{array}{c}\text { Pervious area Manning's } \\
\text { roughness }\end{array}$ & 0.4 & $0.014 \sim 0.8$ \\
\hline & Roughness & $0.01 \sim 0.013$ & $0.01 \sim 0.012$ \\
\hline \multirow{2}{*}{$\begin{array}{l}\text { Depth of depression } \\
\text { storage }\end{array}$} & $\begin{array}{l}\text { Impervious area depression } \\
\text { storage }\end{array}$ & $1 \mathrm{~mm}$ & $0.2 \mathrm{~mm} \sim 2 \mathrm{~mm}$ \\
\hline & $\begin{array}{c}\text { Pervious area depression } \\
\text { storage }\end{array}$ & $10 \mathrm{~mm} \sim 11 \mathrm{~mm}$ & $2 \mathrm{~mm} \sim 13 \mathrm{~mm}$ \\
\hline \multirow{3}{*}{ Horton } & Maximum infiltration volume & $103.81 \mathrm{~mm} / \mathrm{h}$ & $50 \mathrm{~mm} / \mathrm{h} \sim 150 \mathrm{~mm} / \mathrm{h}$ \\
\hline & Minimum infiltration volume & $11.44 \mathrm{~mm} / \mathrm{h}$ & $0 \sim 20 \mathrm{~mm} / \mathrm{h}$ \\
\hline & Drying Time & 2 7 day & 7 day \\
\hline
\end{tabular}

Table 4. Calibration and validation results of the rainfall-runoff model.

\begin{tabular}{|c|c|c|c|c|c|c|}
\hline Event & $\begin{array}{c}\text { Rainfall } \\
\text { Duration (min) }\end{array}$ & $\begin{array}{c}\text { Rainfall } \\
\text { (mm) }\end{array}$ & NSE & $R^{2}$ & $\begin{array}{c}\text { Discharge } \\
\text { Relative Error } \\
(\%)\end{array}$ & $\begin{array}{c}\text { Flood Peak } \\
\text { Relative Error } \\
(\%)\end{array}$ \\
\hline \multirow{5}{*}{$\begin{array}{c}\text { Calibrated } \\
\text { events }\end{array}$} & 140 & 21.4 & 0.92 & 0.93 & 2.84 & 2.18 \\
\hline & 260 & 25 & 0.91 & 0.92 & 2.91 & 1.54 \\
\hline & 210 & 19.7 & 0.92 & 0.98 & 4.52 & 3.14 \\
\hline & 320 & 17.9 & 0.90 & 0.94 & 4.01 & 3.38 \\
\hline & 200 & 16.8 & 0.91 & 0.93 & 4.12 & 3.55 \\
\hline \multirow{5}{*}{$\begin{array}{l}\text { Validated } \\
\text { events }\end{array}$} & 540 & 43.3 & 0.78 & 0.911 & 4.01 & 3.56 \\
\hline & 840 & 51.9 & 0.72 & 0.885 & 3.85 & 4.35 \\
\hline & 110 & 8.3 & 0.74 & 0.889 & 5.82 & 3.78 \\
\hline & 480 & 23.9 & 0.71 & 0.884 & 5.91 & 4.08 \\
\hline & 650 & 34.6 & 0.73 & 0.867 & 6.88 & 7.08 \\
\hline
\end{tabular}

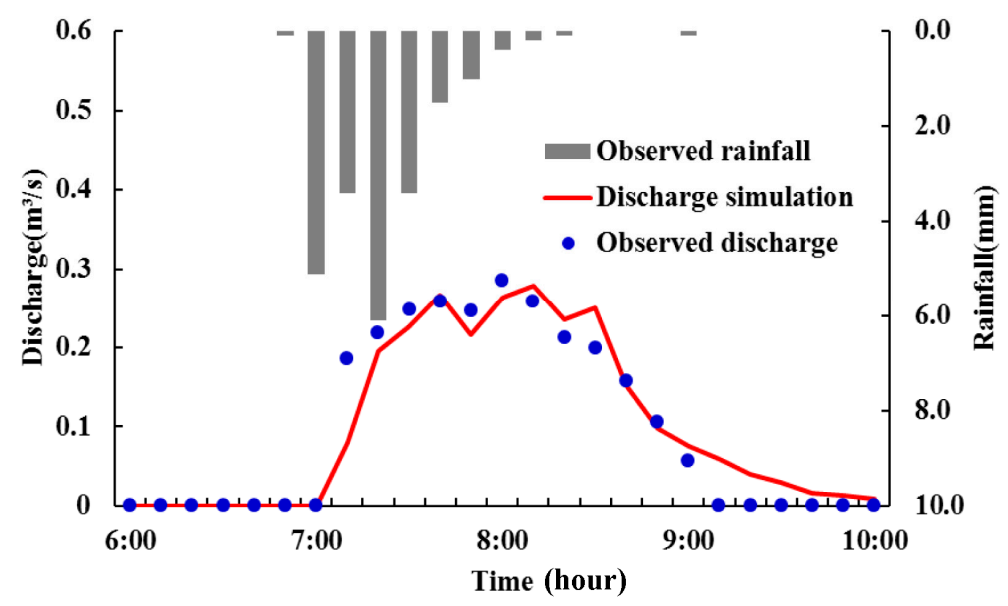

(a) 14 April 2014

Figure 2. Cont. 


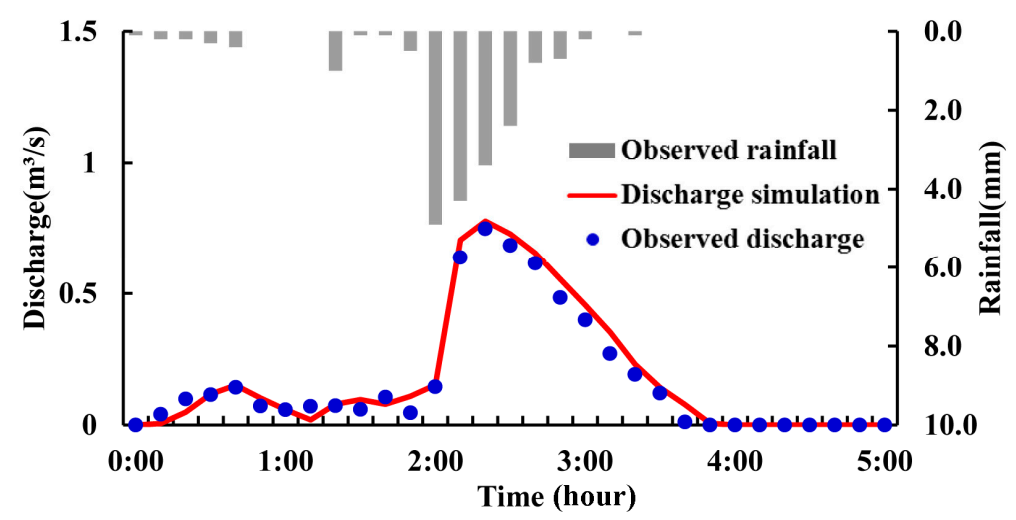

(b) 17 May 2014

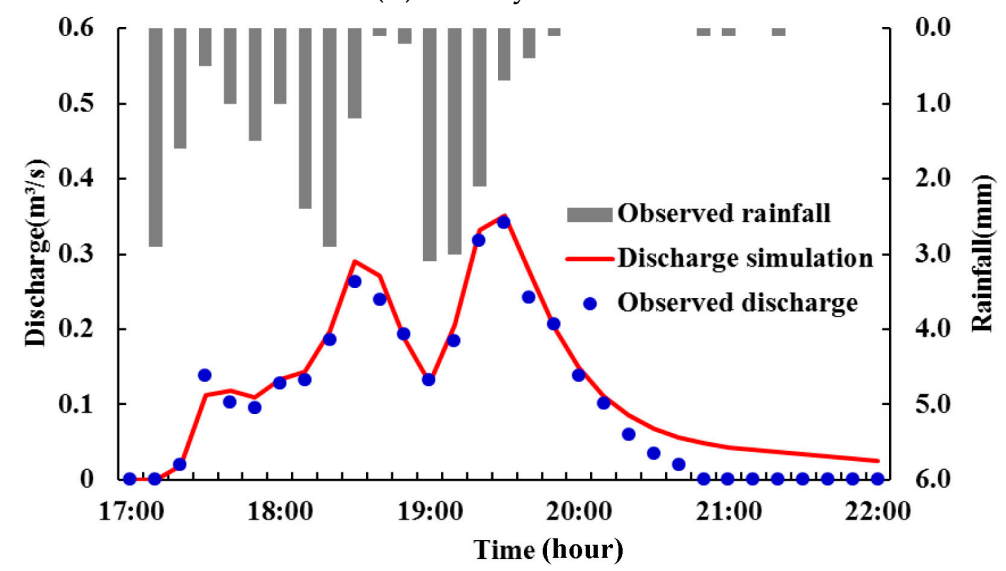

(c) 4 June 2014

Figure 2. The observed and simulated hydrographs.

\subsection{Analyze the Existing Situation of the Drainage System}

To adapt to the changes of rainfall characteristics and land use, the constructed rainfall-runoff model simulates the functioning of the pipe network in different scenarios [38]. As can be seen from Table 5, there are seven to ten overload pipes in the two-year rainfall scenario, and the overload time is more than one hour (Table 5). The drainage system cannot satisfy the designed standard. With the increased rainfall duration or the rainfall peak coefficient, the drainage system is under increasing pressure. To ensure safety, appropriate flood controls must be implemented.

Table 5. Situation of drainage capacity under different rainfall scenarios.

\begin{tabular}{|c|c|c|c|c|c|c|c|c|c|}
\hline $\begin{array}{l}\text { Rainfall } \\
\text { Scenarios }\end{array}$ & $2 \mathrm{y}-2 \mathrm{~h}-0.375$ & $2 y-2 h-0.5$ & $2 y-2 h-0.8$ & $2 y-1.5 h-0.375$ & $2 y-1.5 h-0.5$ & $2 y-1.5 h-0.8$ & $2 y-1 h-0.375$ & $2 y-1 h-0.5$ & $2 y-1 h-0.8$ \\
\hline $\begin{array}{c}\text { Number of } \\
\text { overload pipes }\end{array}$ & 7 & 7 & 10 & 7 & 7 & 10 & 7 & 7 & 9 \\
\hline $\begin{array}{l}\text { Flood volume } \\
\left(\mathrm{m}^{3}\right)\end{array}$ & 2651 & 2789 & 2954 & 2552 & 2733 & 2804 & 2412 & 2629 & 2693 \\
\hline
\end{tabular}

Note: In the Rainfall Scenarios row, y indicates rainfall return period, $\mathrm{h}$ indicates rainfall duration; and the number below $\mathrm{y}$ and $\mathrm{h}$ indicates rainfall peak coefficient.

\subsection{Control Characteristics of LID Practices under Complex Scenarios}

In order to ensure safety and resource conservation, it was evaluated how well LID can contribute to flood control and it's characteristics under complex scenarios were analyzed. Since rain gardens and bioretention swales have better control ability and visual effects than other LID practices, the control characteristics of these two LID practices are analyzed under complex scenarios. The calculation is 
based on the volume of runoff produced by the rainfall as measured once in a two-year period [38]. The layout position is as shown in Figure 1.

\subsubsection{Influence of Rainfall Intensity on Flooding and LID Practices}

To investigate the comprehensive characteristics of floods with changes in rainfall intensity before and after the implementation of LID practices, the comprehensive characteristics of flood distribution under different rainfall scenarios ( $2 \mathrm{y}-2 \mathrm{~h}-0.375,5 \mathrm{y}-2 \mathrm{~h}-0.375,10 \mathrm{y}-2 \mathrm{~h}-0.375)$ were analyzed. As can be seen from Figure 3, before LID practices were taken, the drainage system failed to drain the stormwater runoff produced by the rainfall intensity once in a two-year period and above. As the rainfall intensity increases, the projection values also rise. Figure 3 also illustrates that the flood-affected area increases and the flood become more serious with increasing rainfall intensity. After LID practices are implemented, the drainage system was able to promptly drain the runoff produced by the $2 \mathrm{y}-2 \mathrm{~h}-0.375$ rainfall scenario, and it was rendered free from flooding. However, with the increase in the intensity of the rainfall, the stormwater runoff generated by the $5 \mathrm{y}-2 \mathrm{~h}-0.375$ rainfall scenario caused relatively serious flooding in $\mathrm{J} 9$ and flooding in J15. As rainfall intensity increased to once in ten years, the flood-affected area and flood manholes increased. However, LID practices can alleviate the drainage pressure on the pipe network. It is effective in controlling the flood-affected area and the number of flood manholes, especially under the low intensity rainfall scenario.
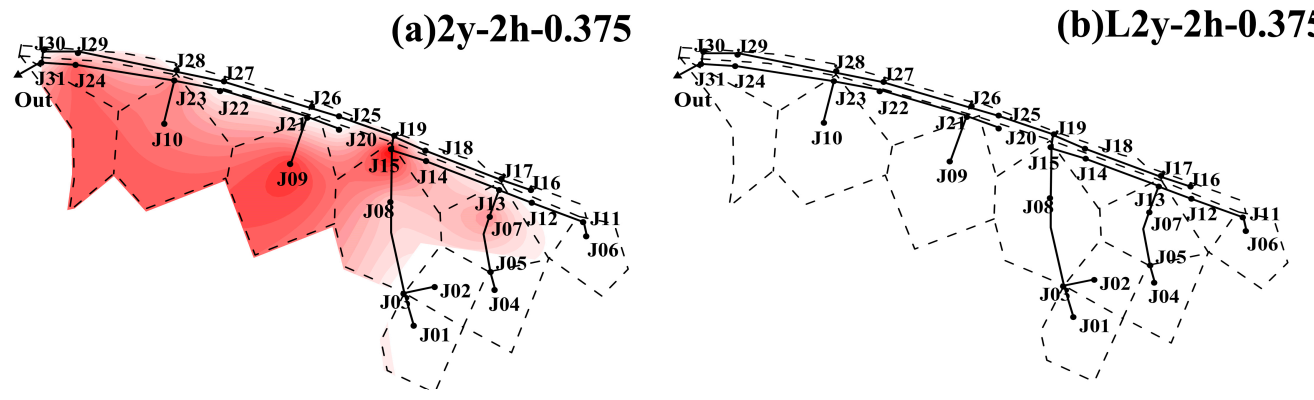

(c) $5 \mathrm{y}-2 \mathrm{~h}-0.375$
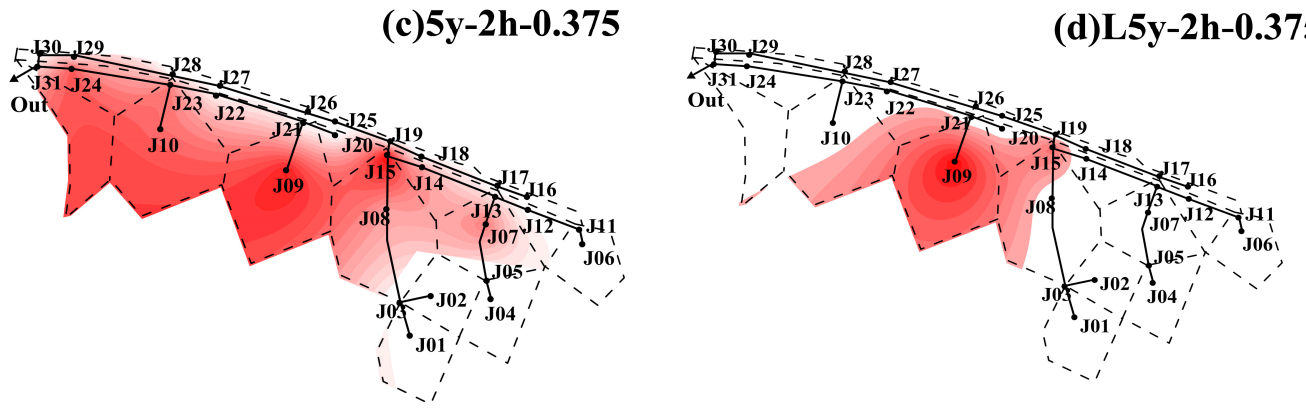

(e)10y-2h-0.375
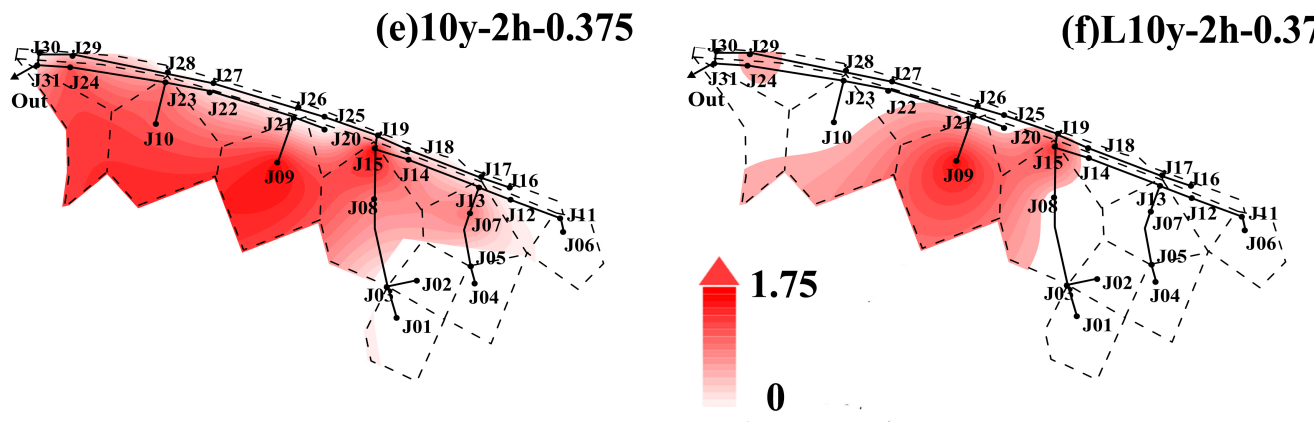

Figure 3. Impact of changes in rainfall intensity on flooding and LID practices. Characteristics of flooding spatial change are reflected by the projection value. $(\mathbf{a}, \mathbf{c}, \mathbf{e})$ show where LID practices are not taken; $(\mathbf{b}, \mathbf{d}, \mathbf{f})$ show where LID practices are taken. 


\subsubsection{Influence of Rainfall Duration on Flooding and LID Practices}

In order to analyze the comprehensive characteristics of the influence of rainfall duration on flooding and LID practices, three rainfall scenarios (5y-1h-0.375, 5y-1.5h-0.375, 5y-2h-0.375) are selected. Before the implementation of LID practices, the flood-affected area and manholes with high projection values change slightly with the increase in rainfall duration (Figure 4). However, flood-affected areas tend to increase, indicating that long-duration rainfall increases flooding. After the implementation of LID practices, the flooding is significantly controlled, and the flood-affected area is drastically reduced. The shorter the rainfall duration, the smaller the flood-affected area. Yet, as rainfall duration increases, the flood-affected range gradually increases.

(a) $5 \mathrm{y}-1 \mathrm{~h}-0.375$

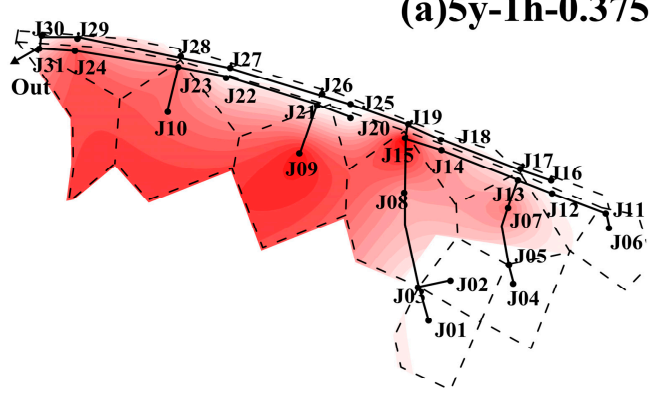

(c) $5 \mathrm{y}-1.5 \mathrm{~h}-0.375$
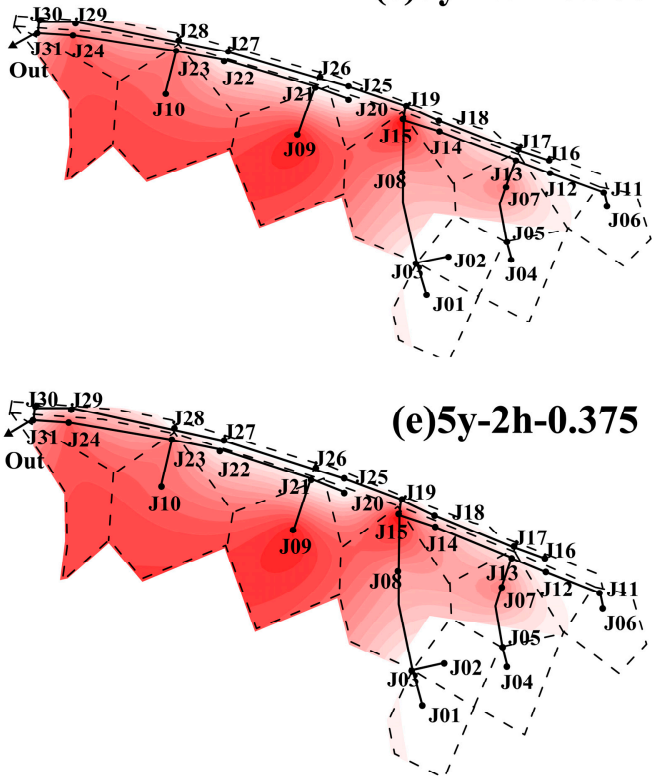

(b)L5y-1h-0.375

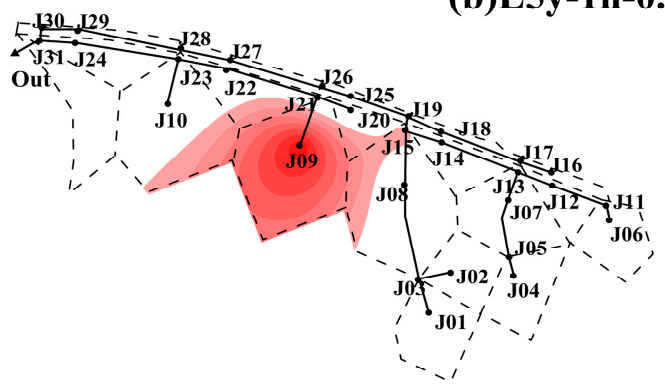

(d)L5y-1.5h-0.375

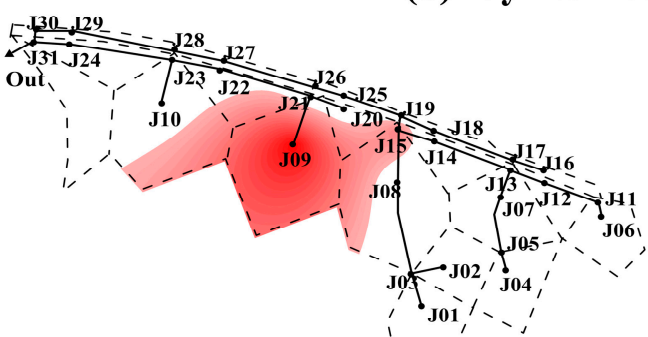

(f)L5y-2h-0.375

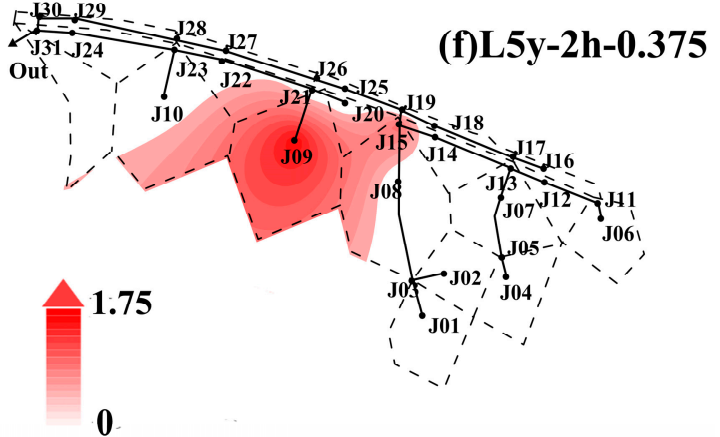

Figure 4. Influence of changes in rainfall duration on flooding and LID practices. Characteristics of flooding spatial change are reflected by the projection value. $(\mathbf{a}, \mathbf{c}, \mathbf{e})$ show where LID practices are not taken; $(\mathbf{b}, \mathbf{d}, \mathbf{f})$ show where LID practices are taken.

\subsubsection{Influence of Rainfall Peak Coefficient on Flooding and LID Practices}

The rainfall peak coefficient is one of the most important factors which influences flooding. Three rainfall scenarios with the same rainfall intensity and duration but different rainfall peak coefficients (5y-2h-0.375, 5y-2h-0.5, 5y-2h-0.8) were selected to analyze the influence of the rainfall peak coefficient on flooding and LID practices. As can be seen from Figure 5, when no LID control practices were taken, the impact of flooding is small with the changes in rainfall peak coefficient. The flood-affected area and the projection values are virtually unchanged. However, the rainfall peak coefficient has some influence on LID practices. The control effects of LID practices are diminished with the increase in the 
rainfall coefficient (Figure 5). The flood-affected area and the projection values of manholes J9 and J15 tended to increase (Figure 5). They are the largest under the 5y-2h-0.8 rainfall scenario.
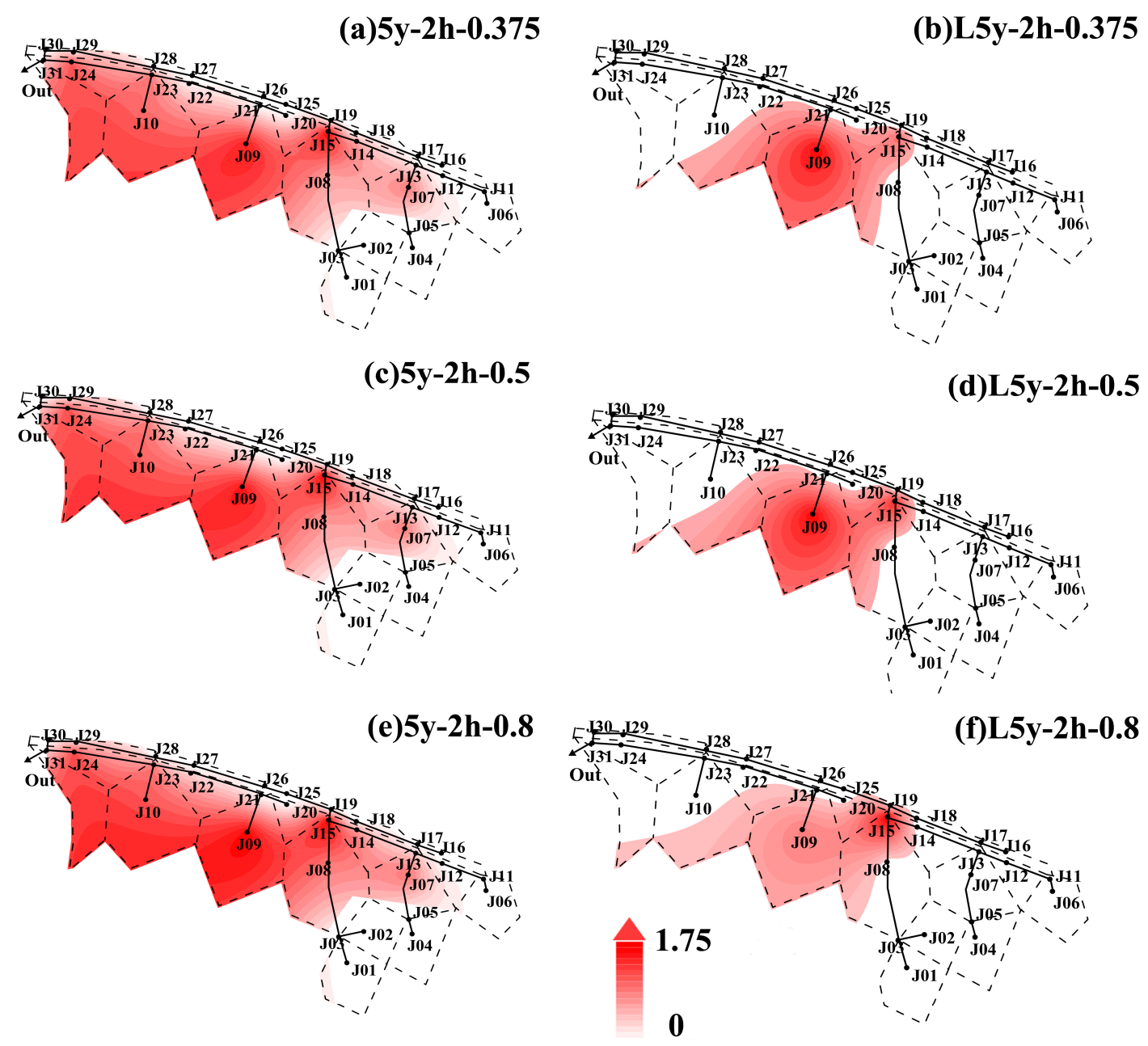

Figure 5. Influence of changes in rainfall peak coefficient on flooding and LID practices. Characteristics of flooding spatial change are reflected by the projection value. $(\mathbf{a}, \mathbf{c}, \mathbf{e})$ show where LID practices are not taken; $(\mathbf{b}, \mathbf{d}, \mathbf{f})$ show where LID practices are taken.

4.3.4. Changes in the Comprehensive Flood and LID Control Characteristics under Different Rainfall Scenarios

According to the comprehensive distribution characteristics of flooding, the projection values of the manholes J9 and J15 and the downstream area are high. The reasons for this are as follows: (i) for J15, it is located in the joint point of two pipes, and therefore its convergence area is large; (ii) J9 covers a large proportion of impervious surface in this area, and therefore rapid convergence speed and the severe overflow of the downstream pipe network contribute to grave flooding. The downstream flooding of the drainage system is caused by the failure of the timely drainage of stormwater, the (overly) full drainage network and the rise of the water level in the manholes.

In order to more comprehensively analyze the change of projection values and the LID control characteristics under complex scenarios, areas in J9 and J15 that have the greatest projection values were selected for analyzing the change characteristics of flooding under different complex rainfall scenarios (Figures 6 and 7). After the implementation of LID practices, the projection values of these two manholes were significantly reduced by at least $28 \%$. However, the projection values increase with the increase in rainfall intensity, rainfall duration or rainfall peak coefficient. With the increase in 
rainfall intensity, there is a more obvious reduction in the impact of rainfall duration and rainfall peak coefficient on projection in the area (J9) with the greater amount of impervious areas. Some similar conclusions are obtained by Qin et al. [29].

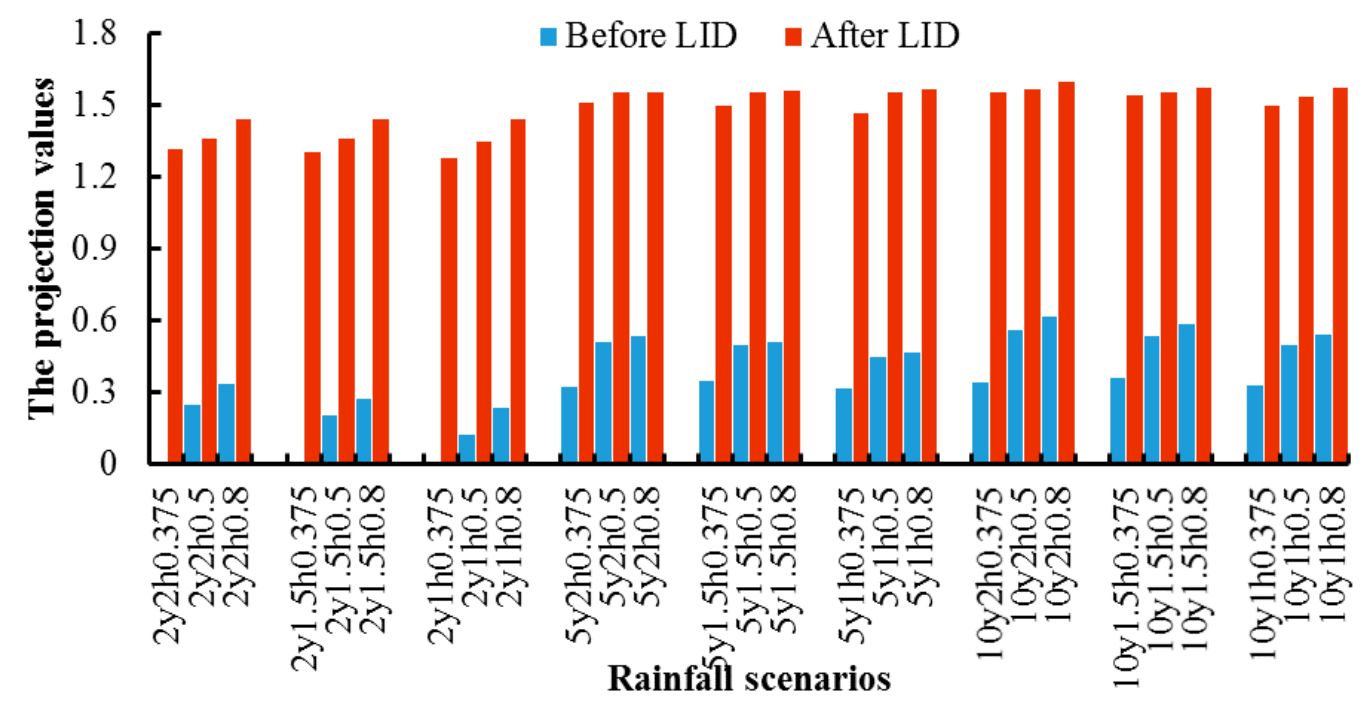

Figure 6. Changes in the projection values of J9 and LID control characteristics under complex scenarios.

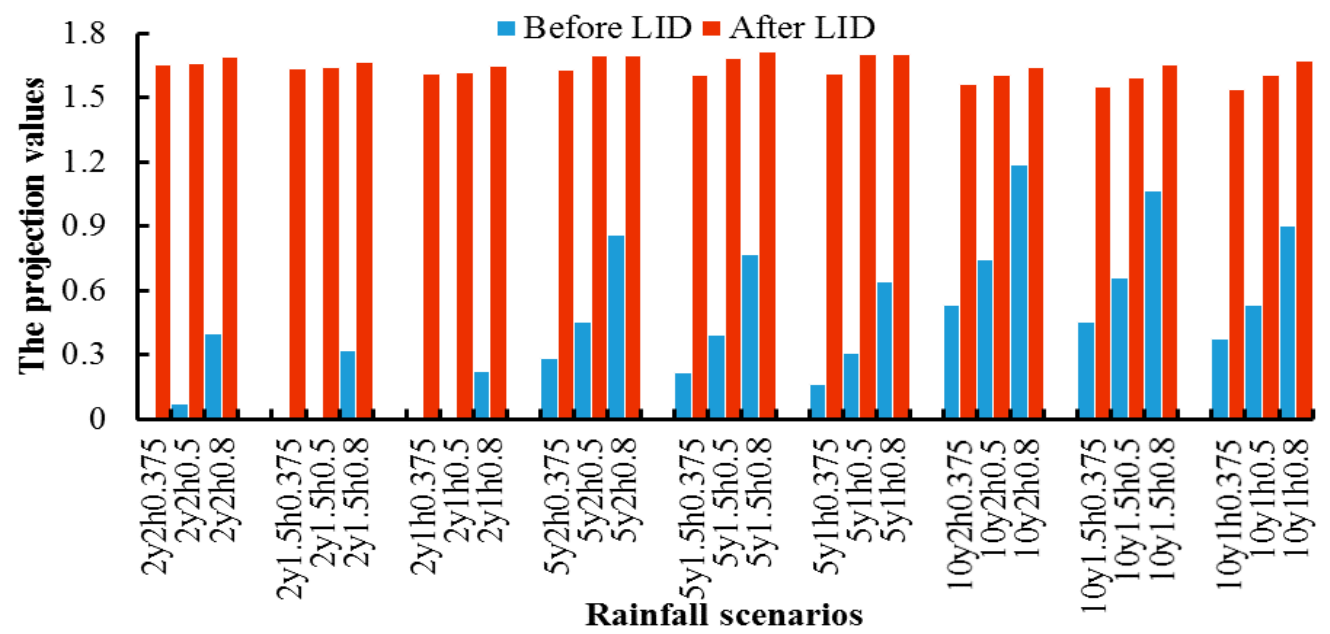

Figure 7. Changes in the projection values of J15 and LID control characteristics under complex scenarios.

It can be seen from the comparison between J9 and J15 that the influence of rainfall intensity, rainfall duration and rainfall peak coefficient on J15 are more obvious than that on J9. This is because LID implementation in J9 accounts for only a small proportion, and its effects on mitigating flooding are limited, making the control characteristics of LID practice not significant. When the rainfall duration is greater than $1.5 \mathrm{~h}$ or the rainfall peak coefficient is greater than 0.5 , the projection value of $\mathrm{J} 9$ increases slightly. However, the upstream and downstream LID practices can alleviate the drainage pressure on the drainage network, thereby reducing the projection values of the areas where no LID practices are taken. On the contrary, the percentage of LID is relatively high upstream (above manhole J15), and the flood control characteristics of the LID practices are more obvious. The projection value of J15 is greater with changes in the rainfall duration and rainfall peak coefficient, suggesting that the area where many LID practices were implemented is significantly affected by rainfall duration and rainfall peak coefficient. 


\section{Conclusions}

Rainfall has a great impact on urban flooding in the drainage system. In this study, the effect of LID practices on flood reduction in a typical residential area of Guangzhou were investigated under different rainfall scenarios. The flooding hot spots and their comprehensive characteristics were analyzed by the SWMM model with the PSO-based projection pursuit technique. The main conclusions were that: (i) the projection values of different manholes have different responses to the changes in rainfall scenarios, but the values of manholes J9 and J15 were the largest before and after the implementation of LID practices. Therefore, manholes J9 and J15 were flooding hotspots and should be paid more attention; (ii) LID practices are effective in flood reduction. They can control the flooding under the $2 \mathrm{y}-2 \mathrm{~h}-0.375$ rainfall scenario. However, the control effects of LID practices tend to decrease as the rainfall intensity, rainfall duration or rainfall peak coefficient increase; (iii) compared with different rainfall scenarios, the control ability of LID practices are more effective in flood reduction for shorter duration, lower intensity and smaller peak coefficient rainfall events; (iv) as the rainfall intensity increases, the impact of rainfall duration and rainfall peak coefficient on projection values is reduced, particularly in the area with the greater amount of impervious areas. Among rainfall intensity, rainfall duration and rainfall peak coefficient, the control effects of LID practices are most affected by rainfall intensity.

Acknowledgments: The research is financially supported by the National Natural Science Foundation of China (Grant No. 91547202, 51210013, 51479216), the Chinese Academy of Engineering Consulting Project (2015-ZD-07-04-03), the Public Welfare Project of Ministry of Water Resources (Grant No. 200901043-03), the Project for Creative Research from Guangdong Water Resources Department (Grant No. 2016-07, 2016-01), Research program of Guangzhou Water Authority (2017).

Author Contributions: Zhihua Zhu and Xiaohong Chen conceived and designed the experiments; Zhihua Zhu performed the experiments; Zhihua Zhu and Xiaohong Chen analyzed the data; Xiaohong Chen contributed reagents/materials/analysis tools; Zhihua Zhu and Xiaohong Chen wrote the paper.

Conflicts of Interest: The authors declare no conflict of interest.

\section{References}

1. Albano, R.; Sole, A.; Mirauda, D.; Adamowski, J. Modelling large floating bodies in urban area flash-floods via a Smoothed Particle Hydrodynamics model. J. Hydrol. 2016, 541, 344-358. [CrossRef]

2. Guinot, V.; Sanders, B.F.; Schubert, J.E. Dual integral porosity shallow water model for urban flood modelling. Adv. Water Resour. 2017, 103, 16-31. [CrossRef]

3. Duan, W.L.; He, B.; Takara, K.; Luo, P.P.; Nover, D.; Yamashiki, Y.; Huang, W.R. Anomalous atmospheric events leading to Kyushu's flash floods, 11-14 July 2012. Nat. Hazards 2014, 73, 1255-1267. [CrossRef]

4. Public Utilities Board of Singapore. Report on Key Conclusions and Recommendations of the Expert Panel on Drainage Design and Flood Protection Measures; PUB: Singapore, 2012.

5. Escuder-Bueno, I.; Castillo-Rodríguez, J.T.; Zechner, S.; Jöbstl, C.; Perales-Momparler, S.; Petaccia, G. A quantitative flood risk analysis methodology for urban areas with integration of social research data. Nat. Hazards Earth Syst. Sci. 2012, 12, 2843-2863. [CrossRef]

6. Parliamentary Office of Science and Technology. Urban Flooding; Postnote Number 289; POST: London, UK, 2007.

7. Chen, S.Y.; Xue, Z.C.; Li, M.; Zhu, X.P. Variable sets method for urban flood vulnerability assessment. Sci. China Technol. Sci. 2013, 56, 3129-3136. [CrossRef]

8. Bubeck, P.; Botzen, W.J.W.; Aerts, J.C.J.H. A review of risk perceptions and other factors that influence flood mitigation behavior. Risk Anal. 2012, 32, 1481-1495. [CrossRef] [PubMed]

9. Lee, J.Y.; Moon, H.J.; Kim, T.I.; Kim, H.W.; Han, M.Y. Quantitative analysis on the urban flood mitigation effect by the extensive green roof system. Environ. Pollut. 2013, 181, 257-261. [CrossRef] [PubMed]

10. Wang, J.; Gao, W.; Xu, S.Y.; Yu, L.Z. Evaluation of the combined risk of sea level rise, land subsidence, and storm surges on the coastal areas of Shanghai, China. Clim. Chang. 2012, 115, 537-558. [CrossRef]

11. Zhu, G.W. Ponderation over the Flood Control Functions of the Artifical Landforms in PRD. Trop. Geogr. 2012, 32, 378-384. 
12. Wesselink, A.; Warner, J.; Syed, M.A.; Chan, F.; Tran, D.D.; Huq, H.; Huthoff, F.; Thuy, N.L.; Pinter, N.; Staveren, M.V.; et al. Trends in flood risk management in deltas around the world: Are we going 'soft'? Int. J. Water Gov. 2015, 3, 25-46. [CrossRef]

13. Tortajada, C.; Joshi, Y.; Biswas, A.K. The Singapore Water Story: Sustainable Development in an Urban City State; Routledge: London, UK; New York, NY, USA, 2013.

14. Chui, S.K.; Leung, J.K.Y.; Chu, C.K. The development of a comprehensive flood prevention strategy for Hong Kong. Int. J. River Basin Manag. 2006, 4, 5-15. [CrossRef]

15. Dietz, M.E. Low impact development practices: A review of current research and recommendations for future directions. Water Air Soil Pollut. 2007, 186, 351-363. [CrossRef]

16. Fletcher, T.D.; Shuster, W.; Hunt, W.F.; Ashley, R.; Butler, D.; Arthur, S.; Trowsdale, S.; Barraud, S.; Semadeni-Davies, A.; Bertrand-Krajewski, J.L.; et al. SUDS, LID, BMPs, WSUD and more. The evolution and application of terminology surrounding urban drainage. Urban Water J. 2015, 12, 525-542. [CrossRef]

17. Ahiablame, L.M.; Engel, B.A.; Chaubey, I. Effectiveness of low impact development practices in two urbanized watersheds: Retrofitting with rain barrel/cistern and porous pavement. J. Environ. Manag. 2013, 119, 151-161. [CrossRef] [PubMed]

18. Seo, M.; Jaber, F.; Srinivasan, R.; Jeong, J.H. Evaluating the Impact of Low Impact Development (LID) Practices on Water Quantity and Quality under Different Development Designs Using SWAT. Water 2017, 9, 193. [CrossRef]

19. PRC Ministry of Construction. Guiding Technology on Constructing the Sponge Cities-Constructing the Rainwater System Based on Low Impact Development; PRC Ministry of Construction: Beijing, China, 2014.

20. Lim, H.S.; Lu, X.X. Sustainable urban stormwater management in the tropics: An evaluation of Singapore's ABC Waters Program. J. Hydrol. 2016, 538, 842-862. [CrossRef]

21. Silva, M.M.; Costa, J.P. Flood adaptation measures applicable in the design of urban public spaces: Proposal for a conceptual framework. Water 2016, 8, 284. [CrossRef]

22. Xia, J.; Zhang, Y.Y.; Xiong, L.H.; He, S.; Wang, L.F.; Yu, Z.B. Opportunities and challenges of the Sponge City construction related to urban water issues in China. Sci. China Earth Sci. 2017, 60, 652-658. [CrossRef]

23. Li, T.; Shan, S.C.; Liu, J.; She, N.; Chen, B.N.; Wu, L.Y. Applying New Features of Low-Impact Development Techniques in the Master Planning of Guangzhou Educational Town. Int. Low Impact Dev. 2015. [CrossRef]

24. Chang, C.G.V. Reimagining Urban Drainage in the World's Biggest Construction Sites: Three LID Stories in Eastern. China Int. Low Impact Dev. 2015. [CrossRef]

25. Jia, H.; Yao, H.; Yu, S.L. Advances in LID BMPs research and practice for urban runoff control in China. Front. Environ. Sci. Eng. 2013, 7, 709-720. [CrossRef]

26. Li, P.; Liu, J.; Fu, R.; Liu, X.; Zhou, Y.Y.; Luan, M. The performance of LID (low impact development) practices at different locations with an urban drainage system: A case study of Longyan, China. Water Pract. Technol. 2015, 10, 739-746. [CrossRef]

27. Rossman, L.A. Storm Water Management Model User's Manual, Version 5.0; National Risk Management Research Laboratory, Office of Research and Development, US Environmental Protection Agency: Cincinnati, $\mathrm{OH}$, USA, 2010.

28. Burszta-Adamiak, E.; Mrowiec, M. Modelling of green roofs' hydrologic performance using EPA's SWMM. Water Sci. Technol. 2013, 68, 36-42. [CrossRef] [PubMed]

29. Qin, H.P.; Li, Z.X.; Fu, G. The effects of low impact development on urban flooding under different rainfall characteristics. J. Environ. Manag. 2013, 129, 577-585. [CrossRef] [PubMed]

30. Alfredo, K.; Montalto, F.; Goldstein, A. Observed and modeled performances of prototype green roof test plots subjected to simulated low-and high-intensity precipitations in a laboratory experiment. J. Hydrol. Eng. 2010, 15, 444-457. [CrossRef]

31. Niu, S.; Cao, L.; Li, Y.; Huang, J.H. Long-Term Simulation of the Effect of Low Impact Development for Highly Urbanized Areas on the Hydrologic Cycle in China. Int. J. Environ. Sci. Dev. 2016, 7, $225-228$. [CrossRef]

32. Bedan, E.S.; Clausen, J.C. Stormwater runoff quality and quantity from traditional and low impact development watersheds. J. Am. Water Res. Assoc. 2009, 45, 998-1008. [CrossRef]

33. Jia, H.; Lu, Y.; Yu, S.L.; Chen, Y. Planning of LID-BMPs for urban runoff control: The case of Beijing Olympic Village. Sep. Purif. Technol. 2012, 84, 112-119. [CrossRef] 
34. Huang, C.L.; Hsu, N.S.; Wei, C.C.; Luo, W.J. Optimal spatial design of capacity and quantity of rainwater harvesting systems for urban flood mitigation. Water 2015, 7, 5173-5202. [CrossRef]

35. Du, S.Q.; Shi, P.J.; Van Rompaey, A.; Wen, J.H. Quantifying the impact of impervious surface location on flood peak discharge in urban areas. Nat. Hazards 2015, 76, 1457-1471. [CrossRef]

36. Zhou, Q.; Leng, G.; Huang, M. Impacts of future climate change on urban flood risks: Benefits of climate mitigation and adaptations. Hydrol. Earth Syst. Sci. Discuss. 2016. [CrossRef]

37. Fang, F.; Qiao, L.L.; Cao, J.S.; Li, Y.; Xie, W.M.; Sheng, G.P.; Yu, H.Q. Quantitative evaluation of $\mathrm{A}_{2} \mathrm{O}$ and reversed $\mathrm{A}_{2} \mathrm{O}$ processes for biological municipal wastewater treatment using a projection pursuit method. Sep. Purif. Technol. 2016, 166, 164-170. [CrossRef]

38. Guangzhou Water Affairs Bureau. The Calculation Formulas and Diagrams of Urban Stormy of Guangzhou; Guangzhou Water Affairs Bureau: Guangzhou, China, 2011.

39. Chen, Z.H.; Yin, L.; Chen, X.H.; Wei, S.; Zhu, Z.H. Research on the characteristics of urban rainstorm pattern in the humid area of Southern China: A case study of Guangzhou City. Int. J. Climatol. 2015, 35, 4370-4386. [CrossRef]

40. Barco, J.; Wong, K.M.; Stenstrom, M.K. Automatic calibration of the US EPA SWMM model for a large urban catchment. J. Hydraul. Eng. 2008, 134, 466-474. [CrossRef]

41. Granata, F.; Gargano, R.; de Marinis, G. Support vector regression for rainfall-runoff modeling in urban drainage: A comparison with the EPA's Storm Water Management Model. Water 2016, 8, 69. [CrossRef]

42. Jang, S.; Cho, M.; Yoon, J.; Yoon, Y.; Kim, S.; Kim, G.; Kim, L.; Aksoy, H. Using SWMM as a tool for hydrologic impact assessment. Desalination 2007, 212, 344-356. [CrossRef]

43. Pushpalatha, R.; Perrin, C.; Le Moine, N.; Andréassian, V. A review of efficiency criteria suitable for evaluating low-flow simulations. J. Hydrol. 2012, 420, 171-182. [CrossRef]

44. Dechmi, F.; Burguete, J.; Skhiri, A. SWAT application in intensive irrigation systems: Model modification, calibration and validation. J. Hydrol. 2012, 470, 227-238. [CrossRef]

45. Yang, X.L.; Zhu, B.; Li, Y.L.; Hua, K.K. Simulation of nonpoint source nitrogen transport in two separated catchments in the hilly area of purple soil. J. Hydraul. Eng. 2013, 44, 1197-1203.

46. Zhao, J.; Jin, J.L.; Guo, Q.Z.; Liu, L.; Chen, Y.Q.; Pan, M. Dynamic risk assessment model for flood disaster on a projection pursuit cluster and its application. Stoch. Environ. Res. Risk Assess. 2014, 28, 2175-2183. [CrossRef]

47. Zhou, Y.; Guo, S.; Xu, C.Y.; Liu, D.; Chen, L.; Ye, Y. Integrated optimal allocation model for complex adaptive system of water resources management (I): Methodologies. J. Hydrol. 2015, 531, 964-976. [CrossRef]

48. Pei, W.; Fu, Q.; Liu, D.; Li, T.X.; Cheng, K. Assessing agricultural drought vulnerability in the Sanjiang Plain based on an improved projection pursuit model. Nat. Hazards 2016, 82, 683-701. [CrossRef]

49. Yang, G.; Guo, S.L.; Li, L.P.; Hong, X.J.; Wang, L. Multi-objective operating rules for Danjiangkou reservoir under climate change. Water Res. Manag. 2016, 30, 1183-1202. [CrossRef]

50. Poli, R.; Rennedy, J.; Blackwell, T. Particle swarm optimization. Swarm Intell. 2007, 1, 33-57. [CrossRef]

51. Gao, Y.; Du, W.B.; Yan, G. Selectively-informed particle swarm optimization. Sci. Rep. 2015, 5, 9295. [CrossRef] [PubMed]

52. Shi, Y. Particle swarm optimization: Developments, applications and resources. In Proceedings of the 2001 Congress on Evolutionary Computation, Seoul, South Korea, 27-30 May 2001; IEEE: New York, NY, USA; Volume 1, pp. 81-86.

53. Zhu, Z.H.; Chen, Z.H.; Chen, X.H.; He, P.Y. Approach for evaluating inundation risks in urban drainage systems. Sci. Total Environ. 2016, 553, 1-12. [CrossRef] [PubMed]

54. Eberhart, R.C.; Shi, Y. Comparing inertia weights and constriction factors in particle swarm optimization. In Proceedings of the 2000 Congress on Evolutionary Computation, La Jolla, CA, USA, 16-19 July 2000; IEEE: New York, NY, USA; Volume 1, pp. 84-88.

55. Wang, Y.C.; Lv, J.; Zhu, L.; Ma, Y.M. Crystal structure prediction via particle-swarm optimization. Phys. Rev. B 2010, 82, 094116. [CrossRef]

56. Guangzhou Water Affairs Bureau. The Calculation Formulas and Diagrams of Urban Stormy of Guangzhou; Guangzhou Water Affairs Bureau: Guangzhou, China, 1993.

(C) 2017 by the authors. Licensee MDPI, Basel, Switzerland. This article is an open access article distributed under the terms and conditions of the Creative Commons Attribution (CC BY) license (http:/ / creativecommons.org/licenses/by/4.0/). 